\title{
Revenue Enhancement and National Corporate Objectives in Nigeria
}

\author{
Charlie Eke Nwekeaku \\ Department of Public Administration, Nasarawa State University, Keffi, Nigeria
}

\begin{abstract}
On attainment of political independence in 1960, the post independent government of Nigeria adopted mixed economic system, which provides for a joint state and private ownership of the means of production, distribution and exchange. The successive post independent regimes made elaborate constitutional provisions in order not to compromise the state responsibility of providing some basic social services, as well as bridging the inequality gap or social distinction in the society. The state requires adequate revenue in order to provide these social amenities. The objective of this paper was to identify strategies for efficient and effective mobilization of revenue for sustainable development of Nigeria. Secondary data, generated through document reading, were used for the analysis. A political economy approach, based on the Marxian concept of the dialectical materialism of the society, was adopted as a theoretical framework. It was discovered that many factors hindered efficient revenue assessment, collection and remittances in Nigeria. The factors include weak institutional framework, lack of adequate and reliable data on tax matters, low quality of monitoring and control, poor tax assessment and collection, selective rewards for tax collectors, double taxation and corruption. One major implication of this scenario is the shortage of revenue to prosecute government social programmes. It is recommended that full application of personal income tax laws, prompt remittances of revenue, synergy among stake holders, stimulating business environment, accountability and transparent governance are the panacea to these problems. Other recommendations include moral rearmament, derivative principle in revenue allocation, equitable distribution of resources, national resource control and a functional educational system.
\end{abstract}

Keywords: Efficiency, strategies, revenue, assessment, collection and remittances

\section{Introduction}

Revenue is a major factor in the income statement of a company or country, as it gives an idea of the financial standing of that company or country. The Investopedia (2013) sees revenue as the amount of money that a company actually receives during a specific period, including discounts and deductions for returned merchandise. Revenue is seen here as the gross receipts by a company regardless of the net profit within a given period.

Revenue may refer to business income in general, or it may refer to the amount, in a monetary unit, received during a period of time, as in last year, Company X had a revenue of $\$ 42$ million. Revenue in accounting is often referred to as the 'top line' due to its position on the income statement at the very top (Wikipedia, 2012).

In a similar vein, the Investopedia (2013) sees revenue as a total amount of money received by a company for goods sold or services provided during a certain time period. It includes all net sales, exchange of assets, interest and any other increase in owners' equity and is calculated before any expenses are subtracted.

It notes that for the government, the increase in assets of governmental funds do not increase liability or recovery of expenditure. This revenue is obtained from taxes, licenses and fees.
Revenue is an important tool of the fiscal policy of the government and it is the opposite factor of government spending (Wikipedia, 2012).

Generally, government the world over, earns revenue from taxes, non- tax income and capital receipts.

Determined to meet its part of social contract with the people, Section 16 of the 1999 Constitution of Federal Republic of Nigeria, under the Economic Objectives and Directive Principles, provides that the government should control the national economy in such manner as to secure the maximum welfare, freedom and happiness of every citizen on the basis of social justice and equality of status and opportunity.

Section $16[\mathrm{~b}]$ of the same Constitution further provides that the state without prejudice to its right to operate or participate in areas of the economy other than the major sectors of the economy, manage and operate the sectors of the economy.

Despite the lofty objectives of the state to promote the wellbeing of all citizens, it has remained a far cry as the country wobbles from one economic woe to another. Major sectors of the economy are underfunded. For example, the power sector, the education sector, agricultural sector, transport and aviation, manufacturing sector, mining, among others, are performing below expectation.

Oil has remained the major foreign exchange earner for the country. The revenue generated from 
other sectors has remained a far cry in meeting societal demands. Many laws, policies, programmes, agencies and measures have been put in place to improve the revenue generation in the country, the result so far have remained a far cry as oil still accounts for over 70 per cent of our foreign exchange earner. One major implication of this inadequate revenue is that government may never be able to provide basic social amenities for the citizens.

This pathetic situation raises some fundamental questions: what is wrong with the revenue generation policy in Nigeria? Why are the revenue generation agencies not living up to their billings? Why do all levels of government scramble for revenue sharing from the Federation Account instead of productivity? Why are Nigerian citizens reluctant to cooperate with government over revenue generation? What are the effective strategies for improve revenue generation, collection and remittance in Nigeria. Answers to the above questions are the foci of this work.

\section{Theoretical Framework}

Theory provides a frame on which research questions are analyzed and interpreted. A Political Economy approach, based on the Marxian concept of the dialectical materialism of the society has been adopted as the theoretical framework. Central to this approach are the primacy of the material conditions of the society, the complex and relatedness of the elements of the society, and the dynamic character of the social reality.

The mode of production of any society forms the basis for understanding man and his social relations. The mode of production of every society consists of the productive forces and social relations of production.

The productive forces comprise the people, the objects and the instruments of production. The social relations of production are determined by the character of the ownership of the means of production, the role they play, the exchange of activities among them and the distribution pattern of their outputs.

Motion and dynamism, predicted on the inherent and complex nature of the related elements determine the social reality. The nature of social interactions among the social classes, as well as the dynamism of the elements determine the intensity of contradictions in the society.

As a theoretical frame work, this paper x-rays the Nigerian historical pattern of the ownership of the means of production, distribution and exchange, as well as the social classes and the nature of their struggles over the national cake, herein called the revenue.

\section{National Corporate Objectives}

The post independent Nigerian government adopted a mixed economic system in order to meet the state obligations to the citizens in keeping with the spirit of social contract. The successive post independent regimes have maintained the mixed economy posture despite some [economic] reforms over the years.

The 1979 Constitution as consolidated by the 1999 Constitution under the fundamental objectives and directive principles of the state policy, made elaborate provisions for the welfare of the people. Section 14[2a] of the 1999 Constitution observes that sovereignty belongs to the people of Nigeria from whom government, through this constitution, derives all its powers and authority.

Section $14[2 \mathrm{~b}]$ further states that the security and welfare of the people shall be the primary purpose of this government.

In order to realize the objectives of section 14 [2b] above, Section $16[1]$ provides that the state shall act as follows:

[a] control the national economy in such manner as to secure the maximum welfare, freedom and happiness of every citizen on the basis of social justice and equality of status and opportunity.

[b] without prejudice to the right of any person to participate in areas of economy other than the major sectors of the economy, manage and operate the major sectors of the economy.

[c] without prejudice to the right of any person to participate in areas of the economy within the major sector of the economy, protect the right of every citizen to engage in any economic activities outside the major sectors of the economy.

To ensure that the above objectives are realized, Section 16[b] further provides that the state shall direct its policy towards ensuring the following:

[a] the promotion of a planned and balanced economic development;

[b] that the material resources of the community are harnessed and distributed as best as possible to serve the common good;

[c] that the economic system is not operated in such a manner as to permit the concentration of wealth or the means of production and exchange in the hands of few individuals or of a group; and

[d] that suitable and adequate shelter, suitable and adequate food, reasonable minimum wage, old age care and pension, and unemployment and sick benefits are provided for all people.

The above provisions, among others, form the basis of the national corporate objectives of the country. Government needs improved and sustained revenue to implement the above provisions, otherwise they may remain mere articles of faith. 


\section{Revenue Generation, Collection and Remittance in Nigeria}

Governments all over the world earn revenue from three major sources, namely, tax revenue, non-tax revenue and capital receipts. Revenue earned by government are received from such sources as tax levied on income and wealth accumulation of individuals and corporations and on goods and services produced, exported and imported from the country. Governments also earn revenue from nontaxable sources, such as, government owned corporations incomes, central bank revenue and capital receipts in the form of external loans and debts from international financial institutions (Wikipedia, 2012).

During Nigeria's colonial days, agriculture was her major foreign exchange earner. Following the discovery of oil in large commercial quantity few years before independence on October 1, 1960 and the gradual neglect of agriculture by successive post independent governments, oil dethroned the later (agriculture) as the main foreign exchange earner. Nigeria became a mono-cultured economy, and successive regimes, both civilian and military, failed to restructure the economy.

The fall of the oil prices in the international market in the 1970s and the failure of the monocultured economy of Nigeria to withstand the shocks of the rampaging oil glut signpost the collapse of the post independent economic development strategies, including the import substitution strategy. The state of the economy became so terrible that Nigeria became a net importer of every important product (Nwekeaku, 2008).

Beginning from 1982, the oil market further plunged, reducing significantly Nigeria's ability to finance the imports, as persistent current accounts deficits began to accumulate, and at a point, foreign suppliers began to dishonour letters of credit [LC] originating from Nigeria. The response of the non oil exports was very small, partly due to the fact that the world prices of non oil commodities that Nigeria exports dropped sharply after 1985 . The potentially positive impact of policies to give incentives to foreign investments was also eroded by unstable political environment, as well as inconsistent macroeconomic policies (Adeyeye, 2002).

Although Nigeria is a federal system with three levels of government she runs a largely centralized system with the Federal Government collecting the major revenue, which include petroleum revenueprofit taxes, royalties, crude oil sales; company income tax, customs and exercise duties, on behalf of the constituent governments (Ekeocha et.al, 2012).

The major components of tax revenue in Nigeria are personal income tax, PIT, companies income tax, CIT, petroleum profit tax, PPT, customs duties, exercise duties, value added tax, VAT, Education tax Act, ETA, capital gains tax, CGT, and stamp duties.

Government revenue may also include reserve bank currency which is printed. This is recorded as an advance to the retail together with a corresponding currency in circulation expense entry, that is, the income derived from the official cash rate payable by retail banks for instruments such as 90 days bill (Wikipedia, 2012).

Despite several tax revenue sources, oil contributes a larger percentage of revenue in Nigeria. Out of the total collection of N4.628 trillion revenue in 2011 by the Federal Inland Revenue Service, FIRS, oil taxes contributed N3.201 trillion, about 64 per cent, while non oil taxes contributed only N1.557 trillion (PwC, 2013).

This means that non oil tax revenue needs drastic measures for significant improvement. The Revenue-Watch (2013) notes that oil revenue totalled $\$ 50.3$ billion in 2011 and generated 70 per cent of government revenue, Nigeria's hydro carbons sector is at cross roads as the current administration attempts to pass the controversial Petroleum Industrial Bill (PIB).

Similarly, out of N701 billion Federal generated revenue in June, 2008, mineral revenue contributed N650 billion, while non-mineral revenue accounted for N71.87 billion (Amaefule, 2008).

In a similar vein Taiwo (2008) in an analysis of revenue structure of Nigeria between 1978 and 2006, noted that while oil revenue rose astronomically from N1.93 billion to N188.32 billion, an average of 13.6 per cent, non oil revenue at the same period rose slightly from N5.42 billion to N24.13 billion at the rate of 4.3 per cent. The analysis further showed that non tax revenue rose from N15.32 billion in 1998 to N115.61 billion in 2006, and averaged N71.19 billion, and accounted for only 2.6 per cent of federally collected revenue. The volatile nature of oil prices at the international market, as well as the domestic environmental challenges, such as, insecurity, oil pipe lines vandalism, oil theft and other environmental challenges that are inimical for sustained production of oil in the Niger Delta are clear alarms to Nigerians that further dependence on oil for our major revenue is dangerous.

Worse still, foreigners control significantly the major means of oil production, distribution and exchange. Even the minimal participation of Nigerians in oil business is terribly hampered by the constitutional provision of federal character and quota system in the recruitment and promotion of personnel in the public service, including Nigeria National Petroleum Company, NNPC, Department of Petroleum Resources, DPR, among others, thereby promoting mediocrity in the key sector of the economy. 


\section{Challenges to Revenue Assessment, Collection and Remittance in Nigeria}

Nigeria has not been able to meet her obligations of enhanced welfare package, adequate food and shelter, reasonable living wage, general security of lives and property of her citizens as contain in the Fundamental Objectives and Directive principles of both the 1979 and the 1999 Constitutions because of her poor revenue base. The collection and management of revenue in Nigeria has some challenges, which may be summarized as follows:

1. Weak institutional mechanism/Framework Most of the institutions invested with powers and authority to collect revenue in the country are generally weak and lack the capacity for efficient and effective revenue collection. A survey by the Revenue Watch (2013) indicated that Nigeria received a weak score of 42 , ranking $40^{\text {th }}$ out of 58 countries. She ranked 40 out of 42 in composite score; and 42 out of58 in reporting practice; and 31 out of 53 in safeguards and quality control.

2. Lack of Adequate and reliable information on tax matters

Lack of contract transparency and incomplete reporting on most aspects of petroleum industry contributed immensely to the country's low score of 38 [Revenue Watch, 2013]. The study notes that while the Federal Ministry of Finance publishes information on production volumes, prices, the value of resource exports, estimates of investments in exploration and development, production costs, costs of subsidies, production stream values, royalties, special taxes, and government share in production sharing contracts; the Petroleum Resources Ministry publishes little information on the upstream licensing process, fiscal and production arrangements, contracts, environmental impact assessments, or operational data.

3. Poor application of personal income tax law The Personal Income Tax Act (LFN 2004;8) empowers the federal and state tax boards to identify taxable adults resident in their areas, assess and tax their income based on the established guidelines under the principle of pay as you earn, [PAYE]. Apart from public servants, private entrepreneurs and other income earners are hardly taxed, and when taxed at all, they are either under taxed or even encouraged to escape payment by tax collectors. Personal income tax has remained so low in the country as mostly public servants pay tax.

In Nigeria, personal income tax laws are not dynamic enough to meet the environmental challenges. Incremental review, rather than holistic and drastic reforms, has been a major draw -back in the assessment, collection and remittances of personal income tax in the country.

4. low quality control/monitoring

Apart from poor assessment and collection of taxes, monitoring of revenue collection agencies and individuals has been very poor, thereby leading to low quality control. Licenses are sometimes awarded to corporate bodies and individuals without recourse to due process. The legislative over sight functions are limited, and, sometimes selective, while the office of the Auditor- General of the Federation publishes, sometimes, audits reports late. Audits of the state owned Nigerian National Petroleum Corporation [NNPC] have never been disclosed. The NNPC operates as an autonomous entity with little or no information on its finances, internal controls, or quasi-fiscal obligations. Its controversial administration of fuel subsidy payments resulted in an estimated $\$ 13$ billion in losses between 2006 and 2011 [Revenue Watch]

5. Poor tax assessment/classification

Poor assessment of individuals and corporate bodies due to partial disclosure of their actual income, as well as poor classification of some sources of revenue have adverse effect on revenue generation in the country. Many Nigerians are reluctant to present themselves for tax assessment, and even when they do, they usually do not declare all their taxable income.

6. Existence of obsolete laws

Some tax laws in Nigeria are colonial heritage and have become obsolete in handling current challenges, especially in licences and fines. Yelwa (2010) notes that the laws governing licences and fines are, in many cases, obsolete. It is not unusual to see licences still fixed in pounds, shelling and pence in Nigeria (after 53 years of political independence and the subsequent adoption of naira as the national currency).

7. Discriminatory/ Selective rewards of revenue collectors

The government discriminatory or selective policy of instant rewards to some revenue collectors has a demoralizing effect on the other collectors who do not enjoy equal treatment. For example, the collectors of oil and gas revenue are allowed to offset their collection expenses before turning in the net revenue to the FGN. Similarly, the collectors of custom duties and corporate income tax are paid $7 \%$ and $4 \%$, respectively of their collections. The collectors of independent revenue are not rewarded instantly (Yelwa, 2010).

8. Delay / non remittances of revenue

Some ministries, agencies and departments [MADs] collect revenue, especially independent revenue, IR, but delay in remitting them or, sometimes, fail to remit at all, and, rather, spend the revenue, contrary to the stipulation of the laws that collected revenue must be remitted within a specified period, usually 30 days.

Section 40 of the FIRS [Establishment] Act 2007 states that any person who is obliged to deduct any tax under this Act or the laws in the First Schedule, but fails to deduct or having deducted, fails to pay to the service within 30 days from the 
date the amount was deducted or the time the duty to deduct arose, is guilty of an offence (Ejemeyovwi, 2010).

9. Double/multiple taxation

Double and multiple taxation of corporate bodies and individuals within the country by different agencies, ministries and departments, MDAs, on the one hand, and among the federal, state and local governments on the other, exist in the country, thereby creating conflicts and confusion in revenue assessment and collection.

\section{Corruption}

Corruption is one of the greatest challenges against tax assessment, collection and remittances in the country. Corruption has robbed the country huge revenue that runs into billions of naira. Corruption is responsible for under assessment of taxable income, delay in remittances of collected revenue, diversion of collected revenue, among other sharp practices among revenue officers in the federation.

\section{Strategies for Enhanced Revenue Drive in Nigeria}

Since revenue is indispensable in meeting the state obligations to the citizens through provision of enhanced welfare package, security of lives and property, adequate food and shelter, improved living standards, good housing and transportation system, employment opportunities, among others, the following strategies are recommended for improved revenue generation, classification, assessment, collection and remittances in Nigeria:

\section{Over -hall of institutional framework for revenue classification and collection}

The institutional framework for revenue assessment, collection and remittances should be over-haled and strengthened to cope with the new development and challenges in the field.

\section{Adequate and reliable information on tax matters}

Regular gathering, processing, dissemination and management of information on tax matters should be encouraged. Reliable, adequate and accurate data on tax matters will reduce the information gap among stake holders.

Full application of personal income tax laws

The personal income tax laws should be applied fully and enforced for general compliance. A holistic overhaul of the personal income laws should be done in order to meet the modern environmental challenges on revenue assessment, collection and remittances. All existing inherited obsolete laws should be either over- haled or abrogated completely.

\section{Prompt remittances of revenue}

All revenue collected by MDAs should be remitted within 30 days, otherwise appropriate sanctions should be applied against defaulting agencies as provided in section 40 of the FIRS[ Establishment] Act 2007.

\section{Effective monitoring/control}

Effective monitoring and control of all revenue agents is imperative as they will sit up to their responsibilities. Effective monitoring will reduce the age old delay in assessment, collection and remittances, as well as diversion of revenue by MDAs. The office of Auditor-General of the Federation, the Fiscal Responsibility Commission, the legislators, the Federal Ministry of Finance, among other monitoring agencies, should sit up to their responsibilities.

Audit reports of public institutions, including NNPC, should be published as and when due.

\section{Equal rewards for all revenue agents}

Selective or discriminatory rewards to revenue collection agents should be discontinued in order to ensure equity, justice and fairness to all. There should be a standard and uniform practice for all of them. What is good for the goose should be good for the gander.

\section{Setting targets}

Targets should be set for MDAs and other stakeholders for the classification, assessment, collection and remittances of revenue.

\section{Immediate stop of double and multiple-taxation}

The Federal and the state boards of revenue, as well as the MDAs should close ranks and look into the issue of double and multiple- taxation and take necessary steps for immediate discontinuation of the exercise.

\section{War against corruption}

A frontal attack on corruption and corrupt practices must be intensified in order to flush out all the bad eggs among revenue agents. Serious sanctions should be imposed on any person or agent involved in corrupt practices. Transparency and accountability should be the watch words of all stake holders in revenue assessment, collection and remittances. 


\section{Synergy among stakeholders}

There should be a synergy among all revenue stakeholders at the federal, state and local governments in order to encourage cooperation, collaboration and effective interaction among them. This will reduce conflicts, duplication of efforts and resources among the stakeholders, thereby improving inter agency relations and boosting revenue collection.

\section{Stimulating and challenging business environment}

Nigerian business environment is one of the costliest in the world. Government provision of basic infrastructure, such as, good road network, regular power supply, clean and portable water, will reduce the cost of business in the country, thereby improving the fortunes of SMEs, and increasing their annual turnover, net profit and taxable income.

\section{Accountability and transparency governance}

Accountability and transparency governance at all levels of government in the country will reassure Nigerians, who have become evasive to tax payment, that public resources are being prudently managed. Unprecedented corruption, arrogant display of ill gotten wealth by some public officers, unimaginable wastage by public institutions give erroneous impression that our governments do not know what to do with money, hence there is no need to pay tax.

\section{Moral rearmament}

There is an urgent need to begin moral rearmament campaign to instil the spirit of patriotism, hard work, creativity, honesty and dignity among Nigerians in order for them to support and promote government drive for more revenue. This also requires leadership by example. The moment citizens begin to see their leaders as competent, disciplined, credible, humble and committed, they will naturally join the bandwagon and support government revenue policies and programmes.

\section{Derivative principle in revenue allocation}

Nigeria should reconsider the use of derivative principle in revenue sharing at all levels of government in the country. If revenue allocation, public projects, programmes and services are done on the basis of the contributions of all stakeholders into the common pool, then every man, community, local government, state, agency and ministry will sit up and struggle for higher productivity.

\section{Equitable distribution of resources}

All tiers of government in the country should ensure equitable distribution of resources in order to give every citizen a sense of belonging. Today, less than 10 per cent of the population of Nigeria controls over 80 per cent of the national resources. This has been the major cause of conflicts, robbery, kidnapping, prostitution, insecurity and instability in various parts of the country.

\section{National resource control}

Oil and gas are the highest revenue earners for Nigeria, yet over 80 per cent of drilling, transportation and marketing activities are done by foreigners and multinational corporations, who apply all forms of technicalities to evade tax payment, thereby aggravating revenue flight from the country.

\section{Over hall of educational system}

The Nigerian educational system needs urgent over hall in order to produce high skilled manpower that can man various sectors of the economy. The continued reliance on foreigners for the operations of the strategic sectors of the economy, such as, oil and gas, power, agriculture, defence, technology and education is a terrible commentary on our match to nationhood.

\section{Conclusion}

The post independent government of Nigeria adopted mixed economic system as a strategy to fulfil the state obligations to her citizens according to the spirit of the social contract between the two parties. To demonstrate its seriousness to uphold the social contract, the Nigerian government made it a constitutional matter as contains in sections 13-22 in both 1979 and 1999 Constitutions under the fundamental objectives and directive principles of state policy.

Specifically, section 16 under the economic objectives stipulates that the state should promote a planned and balanced economic development, provide welfare package, adequate food and shelter, equal and employment opportunities for all, as well as security for the general well being of the citizens. Enormous resources are needed to achieve the above lofty objectives. Regrettably, however, the available revenue is a far cry from the actual needs of the state. This was occasioned by weak institutional frame work, lack of adequate and reliable data on tax matters, poor application of personal income tax laws, low quality of monitoring and control and poor tax assessment and classification. Other factors are delay or diversion of remittances, selective or discriminatory rewards among revenue collectors, double/multiple taxation and corruption. 
The political economy approach, which was adopted as a theoretical framework, emphasizes that whoever controls the means of production, distribution and exchange in any society equally control[s] the political, social, religious, military, technological, educational and other structures in the state. Since foreigners control Nigeria's major means of production, distribution and exchange, it is difficult for the Federal and the constituent governments to perform any magic in revenue generation, assessment, collection and remittances.

In the short run the following measures are recommended: over hall of the institutional frame work for revenue collection; full application of personal income tax laws; prompt remittances of revenue; effective monitoring and control of revenue agencies; equal rewards for all revenue collectors; setting targets for revenue agencies; stopping of double and multiple taxation; war against corruption; synergy among stake holders; stimulating and challenging business environment; and enthronement of accountability and transparency in governance.

In the long run the following measures should be considered: Moral rearmament; derivative principle in revenue allocation and other government services; equitable distribution of resources; national resource control; and immediate over hall of our educational system in order to produce the right manpower for Nigeria's economy. The long term measures will correct all the lapses and imperfections not just on revenue collection, but also the entire economy.

\section{References}

Adeyeye, V.A. (2002). 'The Place of Non-Oil Export,' Sanda, M and Owoeye, J. Eds. Alternative Sources of Funding For the Oil and Gas Industry in Nigeria, Ibadan, Evans Brothers Nigeria Ltd.
Amaefule, E. (2008).' Federal Monthly Revenue Hits N701bn,' The Nigerian Business Communication. Retrieved from: www.thenigeriabusiness.com, July.

Carcello, Joseph. V. (2008) Financial and Managerial Accounting, Irwin, McGraw-Hill

Ekeocha, chukwuemeka, P. (2012). Revenue Implications of Nigeria's Tax System,' Journal of Economics and Sustainable Development, Vol.3, No.8

Ejemeyovwi, Igho A. (2010). 'Tax Deductions at Source, Remittance and Rendition of Returns: Challenges and the Way Forward,' A paper Presented at a Workshop on Revenue Generation, Collection and Remittance,' Organized by Office of Accountant-General, Held in Abuja, November 4.

Enahoro, John A. \& Olabisi, J.Z. (2009) 'Tax Administration and Revenue Generation of lagos State Government of Nigeria,' Research Journal of Finance and Accounting, Vol.3. Issue 3.

Federal Republic of Nigeria (1979). The Constitution, Federal Ministry of Information

Federal Republic of Nigeria (1999), The Constitution, Federal Ministry of information.

Investopedia (2013). Retrieved from: www.investorwords.com/4254/revenue

Nwankwo, B.C., Atakpa,M, \& Ocheni,S (2012). Analysis of Options for Maximizing Local Government Internally Generated Revenue in Nigeria,' Keffi Journal of Administration and Policy Review, Nasarawa Statte Universiy, Keffi Vol.2, No.1

Nwekeaku, C.E.(2008) ' Modalities For Financing of Small and Medium Enterprises, SMEs, In Nigeria,' A Paper Presented at a South East Zone Workshop For Entrepreneurs by the Raw Materials Research and Development Council, RMRDC, July 10-11

Okauru, Ifueko, M (2010),'Need For Collaborative Efforts Among Stakeholders to Strengthen Revenue Generation, Collection and Remittance,' A Paper Presented at a Workshop on Revenue Generation, Collection and Remittance,' by the Office of Account-General of the Federation, Held in Abuja on November 4

PWC (2013) 'Definition of Revenue,' March, www.pwc.com.

Yelwa, Jibril A (2010)' Fiscal Responsibility Act 2007 And The Challenges Of Enforcement On Independent Revenue Drive,' A Paper Presented at a Workshop on Revenue Generation, Collection And Remittance organized by the Office of Accountant-General, Held in Abuja on November 4.

Wikipedia (2012). Revenue,' www.wikipedia.org/wiki/revenue 